\title{
A multi-criteria decision-making approach for comparing sample preservation and DNA extraction methods from swine feces
}

\author{
Sepideh Pakpour ${ }^{1,2}$, Abbas S. Milani ${ }^{3}$, Martin R. Chénier ${ }^{1,4^{*}}$ \\ ${ }^{1}$ Department of Food Science and Agricultural Chemistry, McGill University, Montreal, Canada \\ ${ }^{2}$ Department of Biology, University of British Columbia-Okanagan, Kelowna, Canada \\ ${ }^{3}$ School of Engineering, University of British Columbia-Okanagan, Kelowna, Canada \\ ${ }^{4}$ Department of Animal Science, McGill University, Montreal, Canada \\ Email: ${ }^{*}$ martin.chenier@mcgill.ca
}

Received 22 January 2012; revised 16 February 2012; accepted 28 February 2012

\begin{abstract}
Molecular microbiological methods, such as competetive PCR, real-time PCR, denaturing gradient gel electrophoresis (DGGE) and large-scale parallel-pyrosequencing, require the extraction of sufficient quantity of high quality DNA from microbiologically and chemically complex matrices. Due to difficulties in the field to standardize/select the optimum DNA preservation-extraction methods in view of laboratories differences, this article attempts to present a straightforward mathematical framework for comparing some of the most commonly used methods. To this end, as a case study, the problem of selecting an optimum sample preservation-DNA extraction strategy for obtaining total bacterial DNA from swine feces was considdered. Two sample preservation methods (liquid nitrogen and RNAlater ${ }^{\circledR}$ ) and seven extraction techniques were paired and compared under six quantitative DNA analysis criteria: yield of extraction, purity of extracted DNA ( $A_{260 / 280}$ and $A_{260 / 230}$ ratios), duration of extraction, degradation degree of DNA, and cost. From a practical point of view, it is unlikely that a single sample preservation-DNA extraction strategy can be optimum for all selected criteria. Hence, a systematic multi-criteria decision-making (MCDM) approach was used to compare the methods. As a result, the ZR Fecal DNA MiniPrep ${ }^{\mathrm{TM}}$ DNA extraction kit for samples preserved either with liquid nitrogen or RNAlater ${ }^{\circledR}$ were identified as potential optimum solutions for obtaining total bacterial DNA from swine feces. Considering the need for practicality for in situ applications, we would recommend liquid nitrogen as sample preservation method, along with the ZR Fecal DNA MiniPrep ${ }^{\mathrm{TM}}$ kit. Total bacterial DNA obtained by this strategy can be suitable for downstream PCR-

${ }^{*}$ Corresponding author.
\end{abstract}

based DNA analyses of swine feces.

Keywords: Sample Preservation; DNA Extraction; Swine feces; Multi-Criteria Decision-Making; Weighed Sum Method

\section{INTRODUCTION}

The intestinal tract of animals is a complex ecosystem composed of at least 400 - 500 different microbial species which have critical roles in the nutrition and health of their hosts, including the fermentation of potential energy sources, the production of short chain fatty acids, and the activation or deactivation of carcinogens [1]. Fecal samples are increasingly being investigated using classical microbiological methods and provide valuable information concerning the gut microbiota of animals [2, 3]. However, classical microbiological methods for identifying and characterizing bacteria in the gut microbiota are labor-intensive, time-consuming and limited to the study of microorganisms which are active and can be grown under laboratory conditions [4-8]. These restrictions can be overcome using culture-independent molecular microbiological methods such as competitive PCR, real-time PCR, denaturing gradient gel electrophoresis (DGGE) and large-scale parallel-pyrosequencing, all of which require proper sample preservation and extraction of sufficient quantity of high quality DNA (i.e., free from contaminants and representative of the microbial phylogenetic and/or functional biodiversity of the intestinal microbiota) from samples. Some studies have shown that extracting DNA from organic samples, such as feces and soil, is technically challenging, and that extraction results depend on sample collection and preservation methods $[2,9,10]$. Moreover, feces contain inhibitors such as bile salts, haemoglobin degradation products 
and complex polysaccharides, which can reduce PCR sensitivity by 1000 -fold $[9,11,12]$. Other problems are often encountered in terms of relatively low DNA yields as well as high degradation of extracted DNA [11].

The main criteria in comparing sample preservation methods and DNA extraction techniques include the ability of enhancing the yield of extraction and the purity of extracted DNA (quantified by the $\mathrm{A}_{260 / 280}$ and $\mathrm{A}_{260 / 230}$ ratios), as well as preserving the physical integrity of extracted DNA and removing PCR inhibitory substances [2]. In addition to the aforementioned criteria, the duration and cost of extraction should be considered $[4,13$, 14]. From a practical point of view, it is unlikely that a single sample preservation-DNA extraction strategy can be optimum for all selected criteria. Conflicting (opposite) results may arise when comparing different strategies for a specific criterion or when applying different criteria to a specific strategy. Moreover, the relative importance of selected criteria in ranking sample preservation-DNA extraction strategies is normally defined through the preferences and priorities of the decisionmaker [15].

The motivation of the current work was to address the above reviewed technical and decision-making hurdles in selecting an optimum sample preservation-DNA extraction strategy for obtaining high quality total bacterial DNA from swine feces. Earlier studies have investigated the effect of different sample preservation and/or DNA extraction methods to achieve mainly high yields of extraction, and to obtain PCR-quality total bacterial DNA from fecal samples. To the best of our knowledge, none of these studies on swine fecal samples have systematically considered the level of DNA degradation degree as one of the main criterions to choose an optimum preservation-extraction strategy. Also no earlier work suggested a mathematical decision aid tool to choose the optimum sample preservation-DNA extraction strategy under several conflicting criteria. The present work introduces a systematic/mathematical approach for comparing the performance of different sample preservation-DNA extraction strategies under simultaneous "multiple criteria", i.e. yield of extraction, purity of extracted DNA $\left(\mathrm{A}_{260 / 280}\right.$ and $\mathrm{A}_{260 / 230}$ ratios), duration of extraction, degradation degree of DNA, and cost.

\section{CASE STUDY METHODS}

\subsection{Sample Preservation Methods}

Fresh fecal samples were obtained from a healthy sow (Landrace $\times$ Yorkshire) at the Swine Complex of McGill University (Montreal, QC, Canada) using sterile instruments, taking care not to touch the ground in order to avoid cross contamination, within minutes after defecation. The samples were collected either in sterile $1.5 \mathrm{ml}$ tubes and immediately placed into liquid nitrogen (L), or in sterile $15 \mathrm{ml}$ tubes (kept on ice) to which RNAlater ${ }^{\circledR}$ solution (R) was added according to the manufacturer's instructions (Ambion, Streetsville, ON, Canada). Upon arrival to the laboratory (within $1 \mathrm{~h}$ ), samples in liquid nitrogen were stored at $-80^{\circ} \mathrm{C}$ until DNA extraction, whereas samples in RNAlater ${ }^{\circledR}$ solution were stored at $4^{\circ} \mathrm{C}$ overnight to allow the solution to penetrate the samples; after removing the supernatant, samples were stored at $-80^{\circ} \mathrm{C}$ until DNA extraction.

\subsection{DNA Extraction Techniques}

Total bacterial DNA was extracted from swine feces preserved either in liquid nitrogen or RNAlater ${ }^{\circledR}$ solution by comparing seven extraction techniques (Table 1). The latter included two previously described home-made techniques, as summarized below [a physical-chemical technique (PC) and a freeze-thaw-enzymatic technique (FTE)], as well as five commercial kits, as described by the manufacturers: M: MoBioUltraClean ${ }^{\mathrm{TM}}$ Fecal DNA Kit (MoBio, Carlsbad, CA, USA); Q: QIAamp ${ }^{\circledR}$ DNA Stool Mini Kit (QIAgen, Mississauga, ON, Canada); Z: ZR FecalDNA MiniPrep ${ }^{\text {TM }}$ (Zymo Research, Orange, CA, USA); FSP: FastDNA ${ }^{\circledR}$ SPIN Kit for Feces (MP Biomedicals, Irvine, CA, USA); E: ExtractMaster Fecal ${ }^{\circledR}$ DNA Extraction Kit (Epicentre Biotechnologies, Madison, WI, USA).

1) Physical-Chemical Technique (PC). Five hundred $\mathrm{mg}$ of fecal sample were resuspended in $1.5 \mathrm{ml}$ phosphate buffered saline ( $\mathrm{pH}$ 7.4) (Sigma Aldrich, Oakville, ON, Canada) containing $0.1 \%$ (vol/vol) Tween buffer (Merck, Darmstadt, Germany) and homogenized by vortexing. Five hundred $\mu \mathrm{l}$ of the suspension were transferred into a sterile $1.5 \mathrm{ml}$ tube containing $500 \mu \mathrm{l}$ of lysis buffer $(500 \mathrm{mM}$ Tris- $\mathrm{HCl} \mathrm{pH} 8.0,100 \mathrm{mM} \mathrm{NaCl}, 10 \%$ w/v SDS, $100 \mathrm{mM}$ EDTA) and $1 \mathrm{~g}$ of 0.17 to $0.18 \mathrm{~mm}-$ diameter glass beads (Braun, Melsungen, Germany). Cells were disrupted by shaking the tubes for $40 \mathrm{sec}$ (speed $=$ 6.0) in a Fast-Prep (Bio101 Fast-Prep model FP120, Thermo Savant, Qiagen, Inc., Carlsbad, CA, USA), leaving on ice for $5 \mathrm{~min}$ (to counteract heating of the tubes in the Fast-Prep), and shaking a second time for $40 \mathrm{sec}$ (speed $=6.0$ ). The DNA was purified by phenol-chloroform-isoamyl alcohol extraction (25:24:1) followed by chloroform-isoamyl alcohol extraction (24:1), precipitated with $10 \mathrm{mM}$ ammonium acetate, and washed with $70 \%$ ethanol. After air drying for about $15 \mathrm{~min}$, the pellets were resuspended in $50 \mu \mathrm{l}$ of $1 / 10 \mathrm{TE}$ buffer $(1 \mathrm{mM}$ Tris- $\mathrm{HCl} \mathrm{pH}$ 8.0, $0.1 \mathrm{mM}$ EDTA). The resulting extracts were treated with $10 \mu \mathrm{g}$ of RNAse (Invitrogen, Burlington, ON, Canada) for $5 \mathrm{~min}$ at $37^{\circ} \mathrm{C}$, and preserved at $-20^{\circ} \mathrm{C}$ in $1 / 10 \mathrm{TE}$ buffer [16].

2) Freeze-Thaw-Enzymatic Technique (FTE). One g 
Table 1. DNA extraction techniques used in this study.

\begin{tabular}{|c|c|c|c|c|c|c|c|}
\hline \multirow{2}{*}{ Parameters } & \multicolumn{7}{|c|}{ DNA extraction techniques ${ }^{a}$} \\
\hline & PC & FTE & $\mathbf{M}$ & $\mathbf{Q}$ & $\mathbf{Z}$ & FSP & $\mathbf{E}$ \\
\hline Sample weight (mg) & 500 & 1000 & 250 & 200 & 150 & 200 & 250 \\
\hline Beads & Glass & None & Unknown & None & ZR Bashing beads & $\begin{array}{c}\text { Ceramic }+ \\
\text { garnet }\end{array}$ & None \\
\hline Cell lysis & FastPrep $^{\circledR}$ & Freeze-Thaw & Flat Bed Vortex & $\begin{array}{c}\text { Centrifugation } \\
(14,000 \mathrm{rpm}, 1 \mathrm{~min})\end{array}$ & FastPrep $^{\circledR}$ & FastPrep $^{\circledR}$ & $\begin{array}{l}\text { Vortex at } \\
37^{\circ} \mathrm{C}\end{array}$ \\
\hline $\begin{array}{l}\text { Adsorption of } \\
\text { inhibitors }\end{array}$ & $\mathrm{N} / \mathrm{A}^{\mathrm{b}}$ & $\begin{array}{c}\text { Sodium } \\
\text { lauroyl sarcosinate }\end{array}$ & IRS2 Solution & Inhibitor tablet & $\begin{array}{l}\text { Fecal DNA wash } \\
\text { water }\end{array}$ & N/A & N/A \\
\hline Final volume $(\mu l)$ & 50 & 50 & 50 & 50 & 50 & 50 & 50 \\
\hline
\end{tabular}

${ }^{a}$ : PC: Physical-chemical technique; FTE: Freeze-thaw-enzymatic technique; M: MoBioUltraClean ${ }^{\text {TM }}$ Fecal DNA Kit; Q: QIAamp ${ }^{\circledR}$ DNA Stool Mini Kit; Z: ZR FecalDNAMiniPrep $^{\text {TM}}$; FSP: FastDNA ${ }^{\circledR}$ SPIN Kit for Feces; E: ExtractMaster Fecal ${ }^{\circledR}$ DNA Extraction Kit; ${ }^{\text {b }}$ : N/A: Not available.

of fecal sample was resuspended in $5 \mathrm{ml}$ phosphate buffered saline ( $\mathrm{pH}$ 7.4) (Sigma Aldrich, Oakville, ON, Canada) and homogenized by vortexing. The supernatant was then washed with an equal volume of cold phosphate buffered saline ( $\mathrm{pH}$ 7.4) followed by a second wash with an equal volume of $\mathrm{T}_{10} \mathrm{E}_{25} \mathrm{~S}_{150}$ buffer (10 mM Tris- $\mathrm{HCl}$ pH 8.0, $25 \mathrm{mM}$ EDTA, $150 \mathrm{mM} \mathrm{NaCl}$ ). The cells were pelleted, frozen at $-20^{\circ} \mathrm{C}$ overnight, thawed by re-suspension in $2.5 \mathrm{ml} \mathrm{T}_{10} \mathrm{E}_{25}$ buffer $(10 \mathrm{mM}$ Tris- $\mathrm{HCl} \mathrm{pH} 8.0$, $25 \mathrm{mM}$ EDTA) and $0.25 \mathrm{ml}$ of $2 \mathrm{mg} \cdot \mathrm{ml}^{-1}$ lyzozyme (Invitrogen, Burlington, ON, Canada), and then incubated at $37^{\circ} \mathrm{C}$ in a water bath for $15 \mathrm{~min}$ for cell lysis. Six hundred $\mu 1$ of $19 \%$ sarkosyl-protease solution (Sigma Aldrich, Oakville, ON, Canada) were added and the solution was returned to the water bath for $1 \mathrm{~h}$. The cell lysate was extracted by adding an equal volume of phenol $(\sim 3.5 \mathrm{ml})$, vortexing, centrifuging, and transferring the aqueous phase to a clean tube. The same procedure was repeated three times until minimal debris at the interface remained. Next, chloroform extraction was applied by adding about $3.5 \mathrm{ml}$ chloroform to the phenolic extract and the process was repeated twice. Ammonium acetate (Sigma Aldrich, Oakville, ON, Canada) was added to obtain a final concentration of $0.3 \mathrm{M}$ followed by the addition of an equal volume of isopropanol to make a layer above the DNA solution. The solution was swirled to make it homogeneous and the DNA was removed from the solution by sticking to a sterile pasteur pipette, followed by deep washing with $70 \%$ and $100 \%$ ethanol in series. The pelleted DNA was air dried for about 15 min and re-suspended in $50 \mu \mathrm{l}$ of $\mathrm{T}_{20} \mathrm{E}_{1}(20 \mathrm{mM}$ Tris-HCl $\mathrm{pH}$ 8.0, $1 \mathrm{mM}$ EDTA). Dissolution was completed by incubation in a water bath at $68^{\circ} \mathrm{C}$ for $10 \mathrm{~min}$. The resulting extracts were treated with $10 \mu \mathrm{g}$ of RNAse (Invitrogen, Burlington, $\mathrm{ON}$, Canada) for $5 \mathrm{~min}$ at $37^{\circ} \mathrm{C}$, and preserved at $-20^{\circ} \mathrm{C}$.

\subsection{Quantitative Criteria for DNA Analyses}

Each combination of sample preservation method and DNA extraction technique was repeated three times. The
DNA in each extract was checked for integrity (degradation degree) by agarose gel electrophoresis by comparing with Lambda DNA HindIII Digest standards (New England BioLabs, Ipswich, MA, USA) using AlphaEaseFC software version 3.1.2 (Alpha Innotech Corporation, San Leandro, CA, USA). The degradation degree of the DNA in each extract was evaluated using the scale proposed by Lemarchand et al. [17]; 1 = low (mean fragment size between 23 and $2 \mathrm{~kb}$ ); 2 = medium (mean fragment size between 23 and $0.5 \mathrm{~kb}$ ); $3=$ high (mean fragment size between 23 and $<0.5 \mathrm{~kb}$ ).

DNA concentration, $\mathrm{A}_{260 / 280}$ ratio and $\mathrm{A}_{260 / 230}$ ratio of each extract were determined using a NanoDrop 2000 Spectrophotometer (Thermo Fisher Scientific, Marietta, $\mathrm{OH}, \mathrm{USA})$. The yield of extraction for each combination of sample preservation method and DNA extraction technique was calculated as follows: Yield of extraction ( $\eta$ of DNA/mg of sample) = concentration of DNA in the extract $(\eta g / \mu l) \times$ final volume of extract $(\mu \mathrm{l}) /$ wet weight of sample (mg). The $A_{260 / 280}$ ratio (absorbance at $260 \mathrm{\eta m} /$ absorbance at $280 \eta \mathrm{m}$ ) and the $\mathrm{A}_{260 / 230}$ ratio (absorbance at $260 \eta \mathrm{m} /$ absorbance at $230 \mathrm{\eta m}$ ) are used to evaluate the purity of DNA and RNA solutions and extracts. An $\mathrm{A}_{260 / 280}$ ratio of $>1.8$ is recognized as an indication of the purity of DNA solutions and extracts. When the $A_{260 / 280}$ ratio is lower than 1.8 , proteins or other contaminants (co-extracted with DNA) that absorb strongly at or near $280 \eta \mathrm{m}$ may be present. An $\mathrm{A}_{260 / 230}$ ratio between 2.0 and 2.2 is recognized as an indication of the purity of DNA solutions and extracts. When the $\mathrm{A}_{260 / 230}$ ratio is lower than 2, carbohydrates, phenol, guanidine $\mathrm{HCl}$ or other contaminants that absorb at or near 230 ๆm may be present [18].

\subsection{Multi-Criteria Decision-Making: Weighted Sum Method (WSM)}

Making decisions based on a set of actions among multiple criteria that have potential conflicts is called multicriteria decision-making (MCDM) [15]. In the present study, six performance criteria $\left(C_{j}, j=1,2, \cdots, 6\right)$ were 
considered including: $\left(\mathrm{C}_{1}\right)$ yield of extraction; $\left(\mathrm{C}_{2}\right) \mathrm{A}_{260 / 280}$ ratio; $\left(\mathrm{C}_{3}\right) \mathrm{A}_{260 / 230}$ ratio; $\left(\mathrm{C}_{4}\right)$ duration of extraction; $\left(\mathrm{C}_{5}\right)$ degree of DNA degradation; and $\left(\mathrm{C}_{6}\right)$ cost of extraction. In order to reveal potential conflicts among the criteria, a one-criterion-at-a-time decision-making strategy was first used. Subsequently, the decision maker was required to weight the criteria in order to arrive at a final decision [19]. The suggested initial set of weights $\left(\mathrm{W}_{\mathrm{j}}, \mathrm{j}=1,2, \cdots\right.$, 6) for each of the above criteria were as follows: $\mathrm{W}_{1}=$ $20 \%, \mathrm{~W}_{2}=20 \%, \mathrm{~W}_{3}=20 \%, \mathrm{~W}_{4}=10 \%, \mathrm{~W}_{5}=20 \%, \mathrm{~W}_{6}=$ $10 \%$. These weights were then incorporated into the so-called "weighted sum method" (WSM), which is one of the most commonly used MCDM approaches to calculate an overall score for each combination of sample preservation-DNA extraction strategies (i.e., each decision alternative) [15]. The formula of WSM is:

$$
\begin{aligned}
\text { Score }_{\mathrm{i}}= & \mathrm{W}_{1} \mathrm{~A}_{\mathrm{i} 1}+\mathrm{W}_{2} \mathrm{~A}_{\mathrm{i} 2}+\mathrm{W}_{3} \mathrm{~A}_{\mathrm{i} 3} \\
& -\mathrm{W}_{4} \mathrm{~A}_{\mathrm{i} 4}-\mathrm{W}_{5} \mathrm{~A}_{\mathrm{i} 5}-\mathrm{W}_{6} \mathrm{~A}_{\mathrm{i} 6} \\
& (\mathrm{i}=1,2, \cdots, 14)
\end{aligned}
$$

Score $_{i}$ is the score of each alternative; $W_{j}(j=1,2, \cdots$, 6) are the weight of criteria; " $i$ " is the alternative number $(i=1,2, \cdots, 14$, note that here we have two sample preservation methods and seven DNA extraction techniques, resulting in 14 preservation-extraction combinations); $\mathrm{A}_{\mathrm{ij}}$ is the normalized averaged experimental value for the alternative $i$ under the criterion $j$. For example, if the $\mathrm{R}-\mathrm{PC}$ (sample preservation-DNA extraction technique) is considered as alternative $\# 1$, and the yield of extraction is considered as criterion \#1, then $a_{11}(i=1, j=1)$ means the normalized average of measured yield of extraction value for the selected sample preservation-DNA extraction strategy. For the first three criteria (yield of extraction, $\mathrm{A}_{260 / 280}$ ratio, $\mathrm{A}_{260 / 230}$ ratio), a “+” sign was used since they are benefit type criteria (the higher, the better), whereas for the last three criteria (duration of extraction, degree of DNA degradation, and cost of extraction), a lower value is desirable and thus a "-" sign was used in calculating the scores of alternatives. It should be noted that for the $A_{260 / 280}$ ratio and $A_{260 / 230}$ ratio criteria, the measured values were between 0 and 2, thus a higher value is desirable. Since the units of the six criteria were different, it was necessary to use the normalized $\mathrm{A}_{\mathrm{ij}}$ values by dividing the original value of each alternative by the sum of all alternative values under each criterion (an example calculation is provided in Table 2). Finally, to assess the sensitivity of decision makers' weights (priorities over the criteria) on the final ranking of the alternatives, the WSM approach was repeated for different sets of weights (see Table 3). The first set of weights represents a microbiologist who assigns less importance to the cost and time of a chosen preservation-extraction method and emphasizes more on the performance of measurements by means of higher yield of extraction, higher pu- rity of extracted DNA, and lower degradation degree of DNA. The second set comes from an analyst whose preference is more on the yield of extraction and has no limitation/concern about the cost of the chosen method. The third set represents a conservative decision maker who gives equal preferences over all the criteria.

Remark: Among several MCDM methods used in different applications [20], the main motivation for choosing WSM in the current work was based on the following: (a) its logic is rational and understandable for practitioners who for the first time in the microbiology field would employ MCDM, (b) the computation process is straightforward and easy to implement in similar fecal extraction procedures, and (c) the importance weights can be incorporated conveniently to capture different preferences of the decision maker.

\subsection{Polymerase Chain Reaction Amplification}

PCR amplifications were carried out in a Veriti ${ }^{\mathrm{TM}}$ Thermal Cycler (Applied Biosystems, Foster City, CA, USA) using $5 \eta \mathrm{g}$ of DNA extracted from each combination of sample preservation method-DNA extraction technique as template. The V3 region of the Bacteria 16S rDNA was targeted using the Bacteria universal primers $341 \mathrm{~F}$ (forward primer: CCT ACG GGA GGC AGC AG) and 534R (reverse primer: ATT ACC GCG GCT GCT GG), which yield amplicons of about $193 \mathrm{bp}$ [21]. The PCR reaction mixture contained $1.5 \mu \mathrm{M}$ of each primer, 250 $\mu \mathrm{M}$ of each dNTP (Amersham Biosciences Corp., Piscataway, NJ, USA), 1.25 U Taq DNA polymerase (Invitrogen, Burlington, ON, Canada), and the PCR buffer supplied with the enzyme $(10 \mathrm{mM}$ Tris- $\mathrm{HCl} \mathrm{pH} 9.0,50 \mathrm{mM}$ $\mathrm{KCl}, 1.5 \mathrm{mM} \mathrm{MgCl}_{2}$ ) [5]. For each DNA extract, the following series of PCR tubes were analyzed for the presence of the $\mathrm{V} 3$ region of the Bacteria 16S rDNA: 1) triplicate PCR tubes with $5 \eta \mathrm{g}$ of extracted DNA; 2) a positive control tube with $5 \eta \mathrm{g}$ of DNA extracted from a pure culture of Pseudomonas aeruginosa ATCC 27853;3) an inhibition control tube with 2.5 ๆg of DNA extracted from a pure culture of P. aeruginosa ATCC 27853 and $2.5 \eta \mathrm{g}$ of DNA extracted from each sample, in order to assess the presence of PCR inhibitors in the extracts; 4) a negative control tube consisting of the reaction mixture without DNA, in order to assess the presence of external or cross-contamination of the PCR reaction mixtures by DNA. The PCR conditions were 5 min of denaturation at $99^{\circ} \mathrm{C}$, followed by $10 \mathrm{~min}$ at $80^{\circ} \mathrm{C}$ during which the Taq DNA polymerase was added (hot start), two cycles of 5 min at $94^{\circ} \mathrm{C}$ (denaturation), $5 \mathrm{~min}$ at $55^{\circ} \mathrm{C}$ (annealing), 2 min at $72^{\circ} \mathrm{C}$ (extension), then 28 cycles of $1 \mathrm{~min}$ at $94^{\circ} \mathrm{C}$ (denaturation), $1 \mathrm{~min}$ at $55^{\circ} \mathrm{C}$ (annealing), $2 \mathrm{~min}$ at $72^{\circ} \mathrm{C}$ (extension), and finally an extension period of $10 \mathrm{~min}$ at $72^{\circ} \mathrm{C}[5]$. 
Table 2. Summary of normalized decision matrix data for six decision criteria for each combination of sample preservation method and DNA extraction technique.

\begin{tabular}{ccccccc}
\hline \multirow{2}{*}{ Combination $^{\mathbf{a}}{ }^{n}$} & \multicolumn{5}{c}{ Normalized decision matrix data $^{\mathbf{b}}$} \\
\cline { 2 - 7 } & $\begin{array}{c}\mathbf{C}_{\mathbf{1}} \\
\text { Yield of extraction }\end{array}$ & $\begin{array}{c}\mathbf{C}_{2} \\
\mathbf{A}_{260 / 280}\end{array}$ & $\begin{array}{c}\mathbf{C}_{3} \\
\mathbf{A}_{260 / 230}\end{array}$ & $\begin{array}{c}\mathbf{C}_{\mathbf{4}} \\
\text { Duration of extraction }\end{array}$ & $\begin{array}{c}\mathbf{C}_{5} \\
\text { DNA degradation }\end{array}$ & $\begin{array}{c}\mathbf{C}_{6} \\
\text { Cost per extraction }\end{array}$ \\
\hline L-PC & 0.22 & 0.04 & 0.02 & 0.13 & 0.14 & 0.02 \\
R-PC & 0.16 & 0.04 & 0.02 & 0.13 & N/A & 0.03 \\
R-FTE & 0.00 & 0.06 & 0.07 & 0.14 & N/A & 0.02 \\
L-M & 0.00 & 0.07 & 0.03 & 0.14 & 0.05 & 0.03 \\
R-M & 0.01 & 0.07 & 0.04 & 0.04 & 0.05 & 0.06 \\
L-Q & 0.01 & 0.07 & 0.04 & 0.04 & 0.14 & 0.08 \\
R-Q & 0.04 & 0.08 & 0.12 & 0.06 & 0.05 & 0.08 \\
L-Z & 0.03 & 0.09 & 0.14 & 0.06 & 0.09 & 0.09 \\
R-Z & 0.11 & 0.08 & 0.11 & 0.02 & 0.09 & 0.08 \\
L-FSP & 0.11 & 0.08 & 0.13 & 0.02 & 0.14 & 0.10 \\
R-FSP & 0.15 & 0.09 & 0.05 & 0.06 & 0.09 & 0.09 \\
L-E & 0.13 & 0.09 & 0.04 & 0.06 & 0.05 & 0.11 \\
R-E & 0.01 & 0.07 & 0.11 & 0.06 & 0.05 & 0.10 \\
\hline
\end{tabular}

${ }^{\mathrm{a}}$ : Sample preservation methods: L: Liquid nitrogen; R: RNAlater ${ }^{\circledR}$. DNA extraction techniques: PC: Physical-chemical technique; FTE: Freeze-thaw-enzymatic technique; M: MoBioUltraClean ${ }^{\mathrm{TM}}$ Fecal DNA Kit; Q: QIAamp ${ }^{\circledR}$ DNA Stool Mini Kit; Z: ZR FecalDNAMiniPrep ${ }^{\mathrm{TM}}$; FSP: FastDNA ${ }^{\circledR}$ SPIN Kit for Feces; E: ExtractMaster Fecal ${ }^{\circledR}$ DNA Extraction Kit; ${ }^{\text {}}$ : Example of calculation: Using the first column of Table 4, the normalized value of $\mathrm{C}_{1}$ for the L-PC method is found as: $0.22=87 /(87+66+2+2+3+3+18+12+46+44+62+53+3+3)$.

Table 3. WSM score for each combination of sample preservation method and DNA extraction technique for different sets of criteria weights $\left(\mathrm{W}_{\mathrm{j}}, \mathrm{j}=1,2, \cdots, 6\right)$.

\begin{tabular}{|c|c|c|c|c|c|c|c|c|c|c|c|c|c|c|c|c|c|}
\hline \multirow{4}{*}{ Combination $^{\mathrm{a}}$} & \multicolumn{17}{|c|}{ Scores of methods } \\
\hline & \multicolumn{6}{|c|}{ Weight set 1} & \multicolumn{6}{|c|}{ Weight set 2} & \multicolumn{5}{|c|}{ Weight set 3} \\
\hline & $\mathbf{W}_{1}$ & $\mathbf{W}_{2}$ & $\mathbf{W}_{3}$ & $\mathbf{W}_{4}$ & $\mathbf{W}_{5}$ & $\mathbf{W}_{6}$ & $\mathrm{~W}_{1}$ & $\mathbf{W}_{2}$ & $\mathbf{W}_{3}$ & $\mathbf{W}_{4}$ & $\mathbf{W}_{5}$ & $\mathbf{W}_{6}$ & $\mathbf{W}_{1}=$ & $\mathbf{W}_{2}=$ & $\mathbf{W}_{3}=\mathbf{W}_{4}$ & $\mathbf{W}_{5}=$ & $\mathbf{W}_{6}$ \\
\hline & 0.2 & 0.2 & 0.2 & 0.1 & 0.2 & 0.1 & 0.3 & 0.15 & 0.15 & 0.2 & 0.2 & $\mathbf{0}$ & $1 / 6$ & $1 / 6$ & $1 / 6 \quad 1 / 6$ & $1 / 6$ & $1 / 6$ \\
\hline L-PC & \multicolumn{6}{|c|}{0.013} & \multicolumn{6}{|c|}{0.021} & \multicolumn{5}{|c|}{-0.001} \\
\hline R-PC & \multicolumn{6}{|c|}{0.010} & \multicolumn{6}{|c|}{0.014} & \multicolumn{5}{|c|}{-0.006} \\
\hline L-FTE & \multicolumn{6}{|c|}{ N/A } & \multicolumn{6}{|c|}{ N/A } & \multicolumn{5}{|c|}{ N/A } \\
\hline R-FTE & \multicolumn{6}{|c|}{ N/A } & \multicolumn{6}{|c|}{ N/A } & \multicolumn{5}{|c|}{ N/A } \\
\hline L-M & \multicolumn{6}{|c|}{0.006} & \multicolumn{6}{|c|}{0.003} & \multicolumn{5}{|c|}{-0.003} \\
\hline R-M & \multicolumn{6}{|c|}{0.004} & \multicolumn{6}{|c|}{0.003} & \multicolumn{5}{|c|}{-0.006} \\
\hline L-Q & \multicolumn{6}{|c|}{0.008} & \multicolumn{6}{|c|}{0.005} & \multicolumn{5}{|c|}{-0.004} \\
\hline $\mathbf{R}-\mathbf{Q}$ & \multicolumn{6}{|c|}{0.027} & \multicolumn{6}{|c|}{0.022} & \multicolumn{5}{|c|}{0.010} \\
\hline $\mathbf{L}-\mathbf{Z}$ & \multicolumn{6}{|c|}{0.034} & \multicolumn{6}{|c|}{0.042} & & & 0.019 & & \\
\hline $\mathbf{R}-\mathbf{Z}$ & & & & 34 & & & & & 0.0 & & & & & & 0.019 & & \\
\hline L-FSP & & & & & & & & & 0.0 & & & & & & 0.002 & & \\
\hline R-FSP & & & & & & & & & 0.0 & & & & & & 0.000 & & \\
\hline L-E & & & & & & & & & 0.0 & & & & & & -0.005 & & \\
\hline R-E & & & & 07 & & & & & 0.0 & & & & & & -0.010 & & \\
\hline
\end{tabular}

${ }^{\text {a }}$ : Sample preservation methods: L: Liquid nitrogen; R: RNAlater ${ }^{\mathbb{B}}$. DNA extraction techniques: PC: Physical-chemical technique; FTE: Freeze-thaw-enzymatic technique; M: MoBioUltraClean ${ }^{\mathrm{TM}}$ Fecal DNA Kit; Q: QIAamp ${ }^{\circledR}$ DNA Stool Mini Kit; Z: ZR FecalDNAMiniPrep ${ }^{\mathrm{TM}}$; FSP: FastDNA ${ }^{\circledR}$ SPIN Kit for Feces; E: ExtractMaster Fecal ${ }^{\circledR}$ DNA Extraction Kit; ${ }^{\text {b}}$ : Example of calculation using the first column of Table 2, the WSM score of the L-PC method using the weight set 1 is found as: $0.013=(0.2 \times 0.22)+(0.2 \times 0.04)+(0.2 \times 0.02)-(0.1 \times 0.13)-(0.2 \times 0.14)-(0.1 \times 0.02)$. 


\section{RESULTS AND DISCUSSION}

\subsection{Sample Preservation Methods}

Samples preserved by liquid nitrogen (L) offered identical (FTE, M, E) or higher (PC, Q, Z, FSP) yields of extracted DNA than samples preserved by RNAlater ${ }^{\circledR}(\mathrm{R})$ (Table 4). In contrast, samples preserved by RNAlater ${ }^{\circledR}$ showed similar (M, Z, E) or less DNA degradation (PC, Q, FSP) than samples preserved by liquid nitrogen (Figure 1 and Table 4). Various physical shearing, freezethawing, nucleases and other physical and chemical mechanisms can cause degradation of DNA during storage or extraction [22]. According to the manufacturer of the RNAlater ${ }^{\circledR}$ solution, samples can be kept for longer periods of time under conditions where DNA degradation would usually be expected to occur [23]. Also, earlier studies illustrated that RNAlater ${ }^{\mathbb{R}}$ as a liquid-based commercial nucleic acid preservative solution provides satisfactory concentrations of high-quality RNA and DNA $[2,24]$. Our results are in agreement with the latter studies in that RNAlater ${ }^{\circledR}$ reduces DNA degradation of fecal samples during sampling and storage. However, in the present study the yields of extracted DNA from samples preserved with RNAlater ${ }^{\mathbb{B}}$ were equal to or lower than the yields obtained with samples preserved in liquid nitrogen. No trend could be determined with respect to the impact of sample preservation methods on the purity $\left(\mathrm{A}_{260 / 280}\right.$ and $\left.\mathrm{A}_{260 / 230}\right)$ of DNA extracts, and the cost of RNAlater ${ }^{\circledR}$ represented an additional dollar for each extraction in comparison to liquid nitrogen (Table 4).

\subsection{Combined Sample Preservation and DNA Extraction Strategies}

The physical-chemical extraction technique (L-PC and R-PC) showed the highest yield of extraction (Figure 2(a)) and the lowest cost (Figure 2(f)), but ranked last when the purity of extracted DNA was considered (Figures 2(b) and (c)). L-PC and R-PC generated high and medium level of DNA degradation, respectively (Figure 2(e)), and the duration of DNA extraction for L-PC and R-PC was the longest after L-FTE and R-FTE (Figure 2(d)). Although previous studies demonstrated that the bead beating (PC) is an effective DNA and RNA extraction method [25-27], our results confirm that this effectiveness is mainly under the yield of extraction criterion, and not necessarily under the other criteria.

The freeze-thaw-enzymatic extraction techniques (LFTE and R-FTE) were among the most inexpensive ones (Figure 2(f)), but performed poorly when other criteria were considered: L-FTE and R-FTE showed the lowest yield of extraction (Figure 2(a)), and ranked respectively $12^{\text {th }}$ and $11^{\text {th }}$ for $\mathrm{A}_{260 / 280}$ ratio (Figure 2(b)), $7^{\text {th }}$ and $12^{\text {th }}$

Table 4. Performance of each combination of sample preservation method and DNA extraction technique for six decision criteria.

\begin{tabular}{|c|c|c|c|c|c|c|}
\hline \multirow[b]{2}{*}{ Combination $^{a}$} & \multicolumn{6}{|c|}{ Decision criteria } \\
\hline & $\begin{array}{c}\mathbf{C}_{1} \\
\text { Yield of extraction }^{\mathbf{b}} \\
\text { (ng of DNA/mg of sample) }\end{array}$ & $\begin{array}{c}\mathrm{C}_{2} \\
\mathrm{~A}_{260 / 280}\end{array}$ & $\begin{array}{c}\mathrm{C}_{3} \\
\mathrm{~A}_{260 / 230}\end{array}$ & $\begin{array}{c}\mathrm{C}_{4} \\
\text { Duration of } \\
\text { extraction }(\mathrm{h})\end{array}$ & $\underset{\substack{\mathrm{C}_{5} \\
\text { degree }^{c}}}{\text { DNA degradation }}$ & $\begin{array}{c}\mathrm{C}_{6} \\
\text { Cost per extraction } \\
\left(\mathrm{CAD}^{\mathrm{e}}\right)\end{array}$ \\
\hline L-PC & $87 \pm 5$ & $0.97 \pm 0.09$ & $0.25 \pm 0.02$ & 4.00 & 3 & 1.00 \\
\hline R-PC & $66 \pm 2$ & $0.91 \pm 0.04$ & $0.22 \pm 0.01$ & 4.00 & 2 & 2.00 \\
\hline R-FTE & $2 \pm 0$ & $1.49 \pm 0.04$ & $0.48 \pm 0.01$ & 4.50 & $\mathrm{ND}^{\mathrm{d}}$ & 2.00 \\
\hline L-M & $3 \pm 0$ & $1.69 \pm 0.14$ & $0.59 \pm 0.03$ & 1.16 & 1 & 3.52 \\
\hline R-M & $3 \pm 0$ & $1.68 \pm 0.11$ & $0.57 \pm 0.05$ & 1.16 & 1 & 4.52 \\
\hline L-Q & $18 \pm 1$ & $1.88 \pm 0.02$ & $1.65 \pm 0.12$ & 1.75 & 3 & 4.58 \\
\hline R-Q & $12 \pm 0$ & $1.94 \pm 0.06$ & $1.97 \pm 0.15$ & 1.75 & 1 & 5.58 \\
\hline $\mathrm{L}-\mathrm{Z}$ & $46 \pm 5$ & $1.90 \pm 0.01$ & $1.58 \pm 0.09$ & 0.50 & 2 & 4.8 \\
\hline $\mathrm{R}-\mathrm{Z}$ & $44 \pm 2$ & $1.73 \pm 0.29$ & $1.90 \pm 0.36$ & 0.50 & 2 & 5.8 \\
\hline L-FSP & $62 \pm 0$ & $1.97 \pm 0.02$ & $0.71 \pm 0.12$ & 1.75 & 3 & 5.29 \\
\hline R-FSP & $53 \pm 3$ & $1.95 \pm 0.01$ & $0.52 \pm 0.07$ & 1.75 & 2 & 6.29 \\
\hline L-E & $3 \pm 0$ & $1.53 \pm 0.09$ & $1.54 \pm 0.15$ & 2.00 & 1 & 6.15 \\
\hline R-E & $3 \pm 0$ & $1.57 \pm 0.14$ & $1.34 \pm 0.05$ & 2.00 & 1 & 7.15 \\
\hline
\end{tabular}

a: Sample preservation methods: L: Liquid nitrogen; R: RNAlater ${ }^{\circledR}$. DNA extraction techniques: PC: Physical-chemical technique; FTE: Freeze-thaw-enzymatic technique; M: MoBioUltraClean ${ }^{\mathrm{TM}}$ Fecal DNA Kit; Q: QIAamp ${ }^{\circledR}$ DNA Stool Mini Kit; Z: ZR FecalDNAMiniPrep ${ }^{\text {TM}}$; FSP: FastDNA ${ }^{\circledR}$ SPIN Kit for Feces; E: ExtractMaster Fecal ${ }^{\circledR}$ DNA Extraction Kit; ${ }^{b}$ : Each test was repeated three times and the \pm values refer to their standard deviations; ${ }^{\mathrm{c}}$ : DNA degradation degree [17]: 1 = Low (mean fragment size between 23 and $2 \mathrm{~kb}$ ); 2 = Medium (mean fragment size between 23 and $0.5 \mathrm{~kb}$ ); $3=$ High (mean fragment size between 23 and $<0.5 \mathrm{~kb})$; ${ }^{\mathrm{d}}$ : Not determined since extracted DNA was not visible on the agarose gel stained with ethidium bromide; ${ }^{\mathrm{e}}$. Canadian Dollars. 


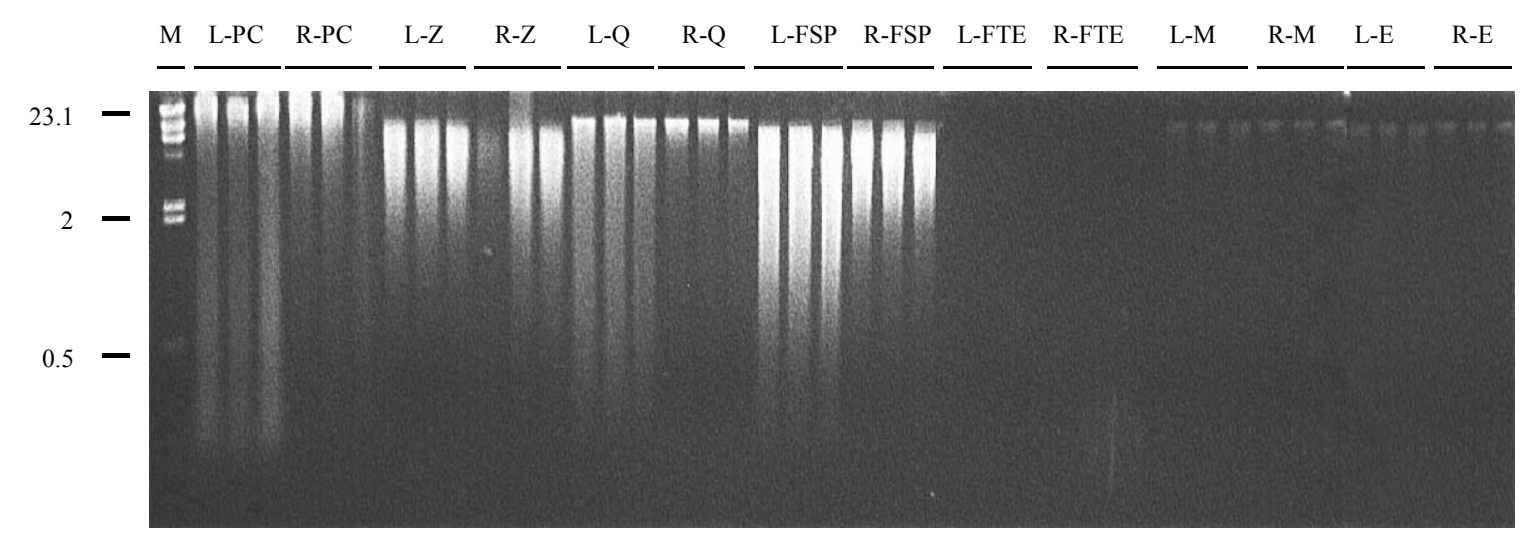

Figure 1. Agarose gel $(1 \% \mathrm{w} / \mathrm{v})$ electrophoresis of the community DNA obtained by each combination of sample preservation method and DNA extraction technique. Sample preservation methods: L: liquid nitrogen; R: RNAlater ${ }^{\mathbb{B}}$. DNA extraction techniques: PC: physical-chemical technique; Z: ZR FecalDNA MiniPrep ${ }^{\text {TM}}$; Q: QIAamp ${ }^{\circledR}$ DNA Stool Mini Kit; FSP: FastDNA ${ }^{\circledR}$ SPIN Kit for Feces; FTE: freeze-thaw-enzymatic technique; M: MoBioUltraClean ${ }^{\mathrm{TM}}$ Fecal DNA Kit; E: ExtractMaster Fecal ${ }^{\circledR}$ DNA Extraction Kit. M: DNA size marker (Lambda DNA digested with HindIII). Numbers on the left of the figure are sizes, in $\mathrm{kb}$.

for the $\mathrm{A}_{260 / 230}$ ratio (Figure 2(c)), and last for the duration of extraction (Figure 2(d)). No band was visualized on the agarose gel, so that the degree of DNA degradation couldn't be assessed (Figure 1).

The MoBioUltraClean ${ }^{\mathrm{TM}}$ Fecal DNA Kit (L-M and R-M) generated among the lowest degree of DNA degradation (Figure 2(e)). Also, it performed well under other criteria including the duration of extraction $\left(2^{\text {nd }}\right.$ rank, Figure 2(d)) and the cost $\left(3^{\text {rd }}\right.$ and $4^{\text {th }}$ ranks, respectively, Figure 2(f)), but lower rankings were obtained when yield of extraction $\left(9^{\text {th }}\right.$ rank, Figure 2(a)), $\mathrm{A}_{260 / 280}$ $\left(7^{\text {th }}\right.$ and $8^{\text {th }}$ ranks, respectively, Figure 2(b)) and $\mathrm{A}_{260 / 230}$ $\left(9^{\text {th }}\right.$ and $10^{\text {th }}$ ranks, respectively, Figure 2(c)) were considered. Pontiroli et al. (2011) [13] had also illustrated that MoBioUltraClean ${ }^{\mathrm{TM}}$ Fecal DNA Kit performs poorly in terms of yield of extraction for both cow and badger faecal samples, but it is affordable in terms of cost.

The QIAamp ${ }^{\circledR}$ DNA Stool Mini Kit (L-Q and R-Q) ranked $7^{\text {th }}$ and $8^{\text {th }}$, respectively, for the yield of extraction (Figure 2(a)), $3^{\text {rd }}$ for the duration of extraction (Figure 2(d)), and $5^{\text {th }}$ and $8^{\text {th }}$, respectively, for the cost (Figure 2(f)). L-Q and R-Q ranked better for $A_{260 / 230}$ ratio (Figure 2(c)) than for $A_{260 / 280}$ ratio (Figure 2(b)), and generated among the highest and lowest degree of DNA degradation, respectively (Figure 2(e)). Our findings using QIAamp ${ }^{\circledR}$ DNA Stool Mini Kit were consistent with the results reported by Scupham et al. [28] regarding moderate yields of extraction from turkey fecal specimens.

Although the extracted DNA using FastDNA ${ }^{\circledR}$ SPIN Kit for Feces did not rank well for $\mathrm{A}_{260 / 230}$ (Figure 2(c)), it showed the best purity when $\mathrm{A}_{260 / 280}$ was considered (Figure 2(b)). The yields of extraction of L-FSP and R-FSP were among the best (Figure 2(a)), however their rankings for the duration (Figure 2(d)) and especially the cost of extraction (Figure 2(f)) were lower. L-FSP and
R-FSP generated among the highest and lowest degree of DNA degradation, respectively (Figure 2(e)). The FSP extraction technique provided the highest yield of extraction in comparison to other test-kits assessed in the present study ( $F S P>Z>Q>M=E$ ), which is in agreement with the results reported by Ariefdjohan et al. [4] (FSP > $\mathrm{Q}>\mathrm{M}$ ) for human fecal samples. In another study, FSP extraction technique has been identified as the best method with the highest DNA recovery in comparison to the MoBioUltraClean ${ }^{\mathrm{TM}}$ and the QIAamp ${ }^{\circledR}$ DNA Stool Mini Kit for badger fecal samples [13].

The ZR FecalDNAMiniPrep ${ }^{\mathrm{TM}}$ (L-Z and R-Z) ranked moderately for the yield of extraction (Figure 2(a)), $\mathrm{A}_{260 / 280}$ (Figure 2(b)), the degree of DNA degradation (Figure 2(e)), and the cost (Figure 2(f)), but ranked first for the duration of extraction, i.e. $30 \mathrm{~min}$ (Figure 2(d)), and $4^{\text {th }}$ and $2^{\text {nd }}$, respectively, for $\mathrm{A}_{260 / 230}$. Stauffer et al. [14] have similarly identified ZR kit as the most preferable and reproducible kit for DNA extraction from feline stool specimens, but in contrast to our observations, they found this kit not user-friendly.

The ExtractMaster Fecal ${ }^{\mathbb{B}}$ DNA Extraction Kit (L-E and R-E) showed the lowest degree of DNA degradation (Figure 2(e)) and ranked $5^{\text {th }}$ and $6^{\text {th }}$, respectively, for $\mathrm{A}_{260 / 230}$ (Figure 2(c)), but performed poorly for other criteria. These results agree with the study by Stauffer $e t$ al. [14] where four DNA extraction methods were compared for the detection of Tritrichomonas foetus in feline stool specimens.

\subsection{Multi-Criteria Decision-Making: Weighted Sum Method}

The MCDM WSM approach was used in this study because potential conflicts were observed among the fourteen sample preservation-DNA extraction strategies un- 


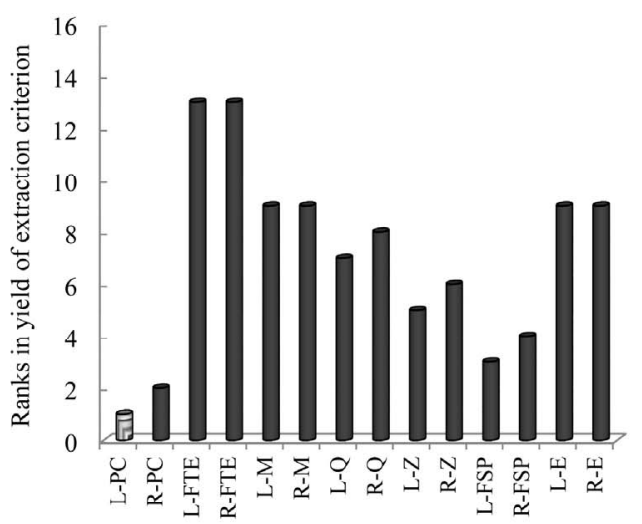

(a) Yield of extraction
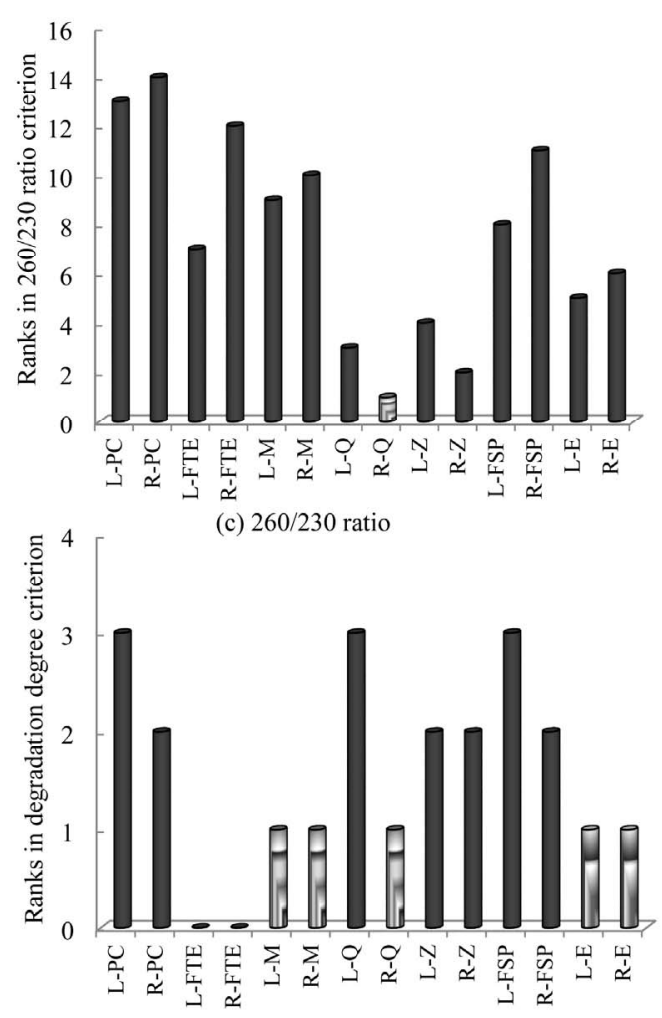

(e) Degree of DNA degradation

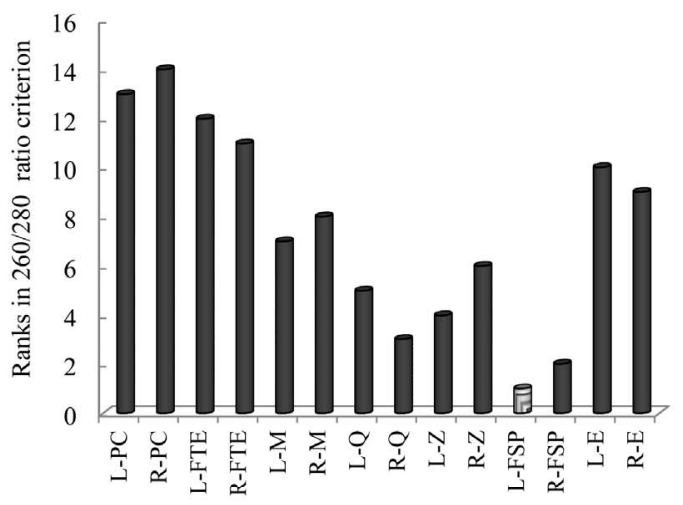

(b) $260 / 280$ ratio

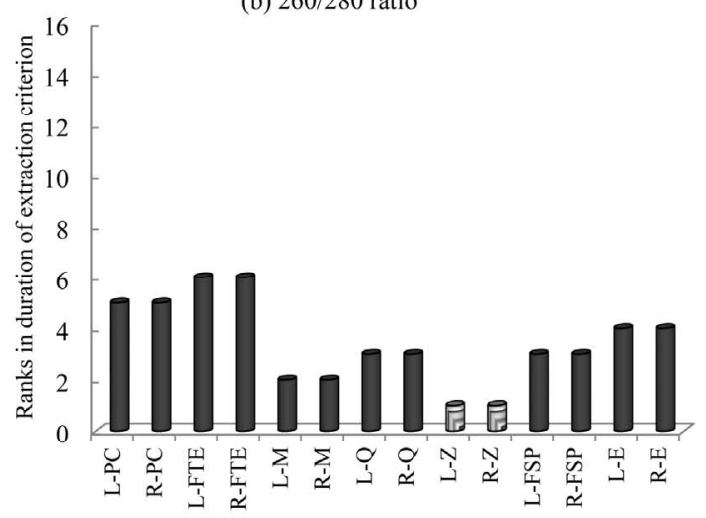

(d) Duration of extraction

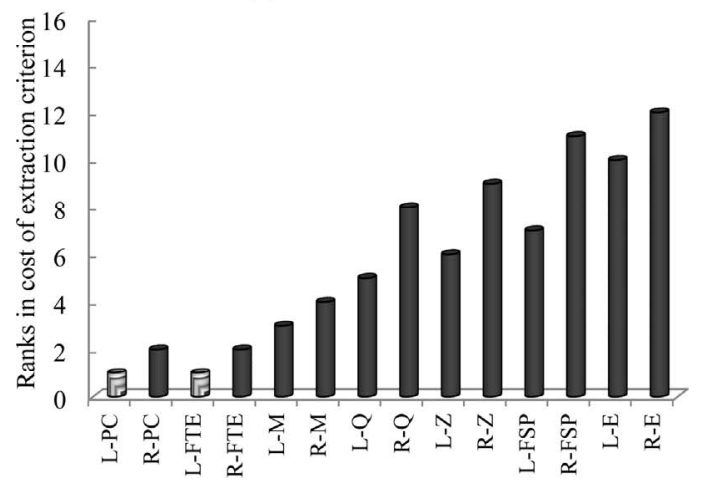

(f) Cost of extraction

Figure 2. Comparison of each combination of sample preservation method-DNA extraction technique for yield of extraction (a), $A_{260 / 280}$ ratio (b), $A_{260 / 230}$ ratio (c), duration of extraction (d), degree of DNA degradation (e) and cost of extraction (f). Sample preservation methods: L: liquid nitrogen; R: RNAlater ${ }^{\mathbb{B}}$. DNA extraction techniques: PC: Physical-chemical technique; FTE: Freeze-thaw-enzymatic technique; M: MoBioUltraClean ${ }^{\mathrm{TM}}$ Fecal DNA Kit; Q: QIAamp ${ }^{\circledR}$ DNA Stool Mini Kit; Z: ZR FecalDNAMiniPrep ${ }^{\text {TM}}$; FSP: FastDNA ${ }^{\circledR}$ SPIN Kit for Feces; E: ExtractMaster Fecal ${ }^{\circledR}$ DNA Extraction Kit.

der the six selected criteria. An example of such conflict can be shown for the physical-chemical extraction technique (L-PC and R-PC) which resulted in a superior performance in terms of yield of DNA extraction, but a high degree of DNA degradation (Table 4 and Figure 2). In contrast, the DNA extracted by the MoBioUltraClean ${ }^{\mathrm{TM}}$ Fecal DNA Kit (L-M and R-M) showed a low degree of degradation (which is desirable), but the yield of extrac- tion was one of the lowest (which is undesirable).

According to the WSM method applied in this work, Table 2 illustrates the normalized $A_{i j}$ values in order to remove the units of the six criteria (an example of calculation is shown in the table). Subsequently, the WSM score of each sample preservation-DNA extraction strategy based on Equation (1) was calculated for three different sets of criteria weights (Table 3). Because no 
DNA band was observed for the freeze-thaw-enzymatic techniques (L-FTE and R-FTE), they were excluded in the subsequent WSM calculations. For the first set of criteria weights $\left(\mathrm{W}_{1}=0.2, \mathrm{~W}_{2}=0.2, \mathrm{~W}_{3}=0.2, \mathrm{~W}_{4}=0.1\right.$, $\left.\mathrm{W}_{5}=0.2, \mathrm{~W}_{6}=0.1\right)$, the sample preservation-DNA extraction strategies scored as follows (decreasing order): L-Z $=$ R-Z $>$ R-Q $>$ L-FSP $=$ R-FSP $>$ L-PC $>$ L-E $>$ R-PC $>$ L-Q $>$ R-E $>$ L-M $>$ R-M. For the second set of criteria weights $\left(\mathrm{W}_{1}=0.3, \mathrm{~W}_{2}=0.15, \mathrm{~W}_{3}=0.15, \mathrm{~W}_{4}=\right.$ $0.2, \mathrm{~W}_{5}=0.2, \mathrm{~W}_{6}=0$ ), the sample preservation-DNA extraction strategies scored as follows (decreasing order): $\mathrm{L}-\mathrm{Z}=\mathrm{R}-\mathrm{Z}>\mathrm{R}-\mathrm{FSP}=\mathrm{L}-\mathrm{FSP}>\mathrm{R}-\mathrm{Q}>\mathrm{L}-\mathrm{PC}>\mathrm{R}-\mathrm{PC}>$ $\mathrm{L}-\mathrm{E}>\mathrm{R}-\mathrm{E}>\mathrm{L}-\mathrm{Q}>\mathrm{L}-\mathrm{M}=\mathrm{R}-\mathrm{M}$. For the last set of criteria weights $\left(\mathrm{W}_{1}=\mathrm{W}_{2}=\mathrm{W}_{3}=\mathrm{W}_{4}=\mathrm{W}_{5}=\mathrm{W}_{6}=1 / 6\right)$, the sample preservation-DNA extraction strategies scored as follows (decreasing order): $\mathrm{L}-\mathrm{Z}=\mathrm{R}-\mathrm{Z}>\mathrm{R}-\mathrm{Q}>\mathrm{L}-\mathrm{FSP}>$ R-FSP $>$ L-PC $>$ L-M $>$ L-Q $>$ L-E $>$ R-PC $=$ R-M $>$ R-E.

\subsection{Selecting an Optimum Sample Preservation-DNA Extraction Strategy}

Under all three sets of criteria weights of the MCDMWSM approach applied in this study, the ZR Fecal DNA MiniPrep $^{\mathrm{TM}}$ extraction technique for samples preserved with liquid nitrogen $(\mathrm{L}-\mathrm{Z})$ or RNAlater $^{(\mathbb{R}}$ (R-Z) were identified as the best strategies with the same scores
(Table 4). It has been previously reported that preserving samples in RNAlater ${ }^{\circledR}$ may facilitate self-collection and delivery of stool samples for comprehensive epidemiologic studies of molecular markers for intestinal bacteria [2]. However, in the present study, we found that when working in situ and/or with animals, e.g. at the Swine Complex of McGill University (Montreal, QC, Canada), it is more practical to preserve sampling tubes in a 2 liter-flask containing liquid nitrogen than adding a fixed volume of RNAlater ${ }^{\mathbb{B}}$ to each sampling tube. Moreover, the preservation of sampling tubes with liquid nitrogen doesn't introduce a fluid into the samples (and hence modify their volume) as is the case with RNAlater $^{\circledR}$. Maintaining the volume/weight of environmental samples is required when quantitative molecular-based microbiological analyses such as real-time PCR are applied. For all the aforementioned reasons, L-Z was identified as the optimum strategy in the present work.

\subsection{PCR Amplification of Bacteria 16S rDNA}

Consistent specific amplification (unique band) of $\sim 193$ bp amplicons corresponding to the V3 region of the Bacteria $16 \mathrm{~S}$ rDNA was successfully obtained for the positive controls as well as for all triplicate extracts obtained from each combination of sample preservation method and DNA extraction technique (Table 5). Possible PCR

Table 5. PCR amplification of total community DNA extracted by each combination of sample preservation method and DNA extraction technique.

\begin{tabular}{|c|c|c|c|c|}
\hline \multirow{2}{*}{ Combination $^{\mathrm{a}}$} & \multicolumn{4}{|c|}{ PCR amplification ${ }^{\mathrm{b}}$} \\
\hline & Extracted DNA (triplicates) & Positive control & Inhibition control & Negative control \\
\hline L-PC & $+/+/+$ & + & + & - \\
\hline $\mathrm{R}-\mathrm{PC}$ & $+/+/+$ & + & + & - \\
\hline L-FTE & $+/+/+$ & + & + & - \\
\hline R-FTE & $+/+/+$ & + & + & - \\
\hline L-M & $+/+/+$ & + & + & - \\
\hline $\mathrm{R}-\mathrm{M}$ & $+/+/+$ & + & + & - \\
\hline L-Q & $+/+/+$ & + & + & - \\
\hline R-Q & $+/+/+$ & + & + & - \\
\hline L-Z & $+/+/+$ & + & + & - \\
\hline $\mathrm{R}-\mathrm{Z}$ & $+/+/+$ & + & + & - \\
\hline L-FSP & $+/+/+$ & + & + & - \\
\hline R-FSP & $+/+/+$ & + & + & - \\
\hline L-E & $+/+/+$ & + & + & - \\
\hline R-E & $+/+/+$ & + & + & - \\
\hline
\end{tabular}

a: Sample preservation methods: L: Liquid nitrogen; R: RNAlater ${ }^{\circledR}$. DNA extraction techniques: PC: Physical-chemical technique; FTE: Freeze-thaw-enzymatic technique; M: MoBioUltraClean ${ }^{\mathrm{TM}}$ Fecal DNA Kit; Q: QIAamp ${ }^{\circledR}$ DNA Stool Mini Kit; Z: ZR FecalDNAMiniPrep ${ }^{\text {TM}}$; FSP: FastDNA ${ }^{\circledR}$ SPIN Kit for Feces; E: ExtractMaster Fecal ${ }^{\circledR}$ DNA Extraction Kit; ${ }^{\text {b }}$ : + indicates specific amplification. - indicates no amplification. Positive control: DNA extracted from Pseudomonas aeruginosa ATCC 27853. Inhibition control: Mixture of DNA extracted from Pseudomonas aeruginosa ATCC 27853 and DNA extracted from each sample (separately). Negative control: No template DNA. 
inhibitors present in fecal material include bile salts, hemoglobin degradation products and complex polysaccharides [9] and the presence of PCR inhibitors in fecal specimens has previously been reported $[2,29]$. However, in the present study, the specific amplification of $\sim 193 \mathrm{bp}$ amplicons was obtained for each extract in the inhibition controls (mixture of DNA extracted from Pseudomonas aeruginosa ATCC 27853 and DNA extracted from each sample), indicating the absence of PCR inhibitors in the extracts from the assessed DNA extraction techniques. Also, no amplification was observed in the negative controls, showing the absence of external or cross-contamination of the PCR reaction mixtures by DNA.

\section{CONCLUDING REMARKS}

Based on the results of the performed case study, we would recommend liquid nitrogen for preserving samples and the ZR Fecal DNA MiniPrep ${ }^{\mathrm{TM}}$ extraction technique as an optimum sample preservation-DNA extraction strategy for obtaining total bacterial DNA from swine feces. DNA obtained by this strategy can be suitable for downstream PCR-based DNA analyses such as competitive PCR, real-time PCR, denaturing gradient gel electrophoresis (DGGE) or large-scale parallel-pyrosequencing.

The standardization/selection of preservation-extraction techniques in the field is a current problem, mainly due to laboratories differences, and hence a simple MCDM approach such as WSM was a first step towards comparing the methods mathematically. The inclusion of more criteria and the application of more advanced MCDM methods such as the Technique for Order Preference by Similarity to Ideal Solution (TOPSIS) $[30,31]$ are recommended as potential future work.

\section{ACKNOWLEDGEMENTS}

This work was supported by the National Sciences and Engineering Research Council of Canada (NSERC-Discovery Grant) and the Canada Foundation for Innovation (CFI-Leaders Opportunity Fund) to M.R.C. S.P. benefited from the CFI-Infrastructure Operating Fund for personal support. The financial support by UBC's Work-Study Program is also greatly acknowledged.

\section{REFERENCES}

[1] McOrist, A.L., Jackson, M. and Bird, A.R. (2002) A comparison of five methods for extraction of bacterial DNA from human faecal samples. Journal of Microbiological Methods, 50, 131-139. doi:10.1016/S0167-7012(02)00018-0

[2] Nechvatal, J.M., Ram, J.L., Basson, M.D., Namprachan, P., Niec, S.R., Badsha, K.Z., Matherly, L.H., Majumdar, A.P.N. and Kato, I. (2008) Fecal collection, ambient preservation, and DNA extraction for PCR amplification of bacterial and human markers from human feces. Journal of Microbiological Methods, 72, 124-132. doi:10.1016/j.mimet.2007.11.007

[3] Zhang, B.W., Li, M., Ma, L.C. and We, F.W. (2006) A widely applicable protocol for DNA isolation from fecal samples. Biochemical Genetics, 44, 503-512. doi:10.1007/s10528-006-9050-1

[4] Ariefdjohan, M.W., Savaiano, D.A. and Nakatsu, C.H. (2010) Comparison of DNA extraction kits for PCRDGGE analysis of human intestinal microbial communities from fecal specimens. Nutrition Journal, 9, 1-8. doi:10.1186/1475-2891-9-23

[5] Chénier, M.R. and Juteau, P. (2009) Impact of an aerobic thermophilic sequencing batch reactor on antibiotic-resistant anaerobic bacteria in swine waste. Microbial Ecology, 58, 773-785. doi:10.1007/s00248-009-9546-4

[6] Chénier, M.R. and Juteau, P. (2009) Fate of chlortetracycline- and tylosin-resistant bacteria in an aerobic thermophilic sequencing batch reactor treating swine waste. Microbial Ecology, 58, 86-97. doi:10.1007/s00248-008-9478-4

[7] Leser, T.D., Amenuvor, J.Z., Jensen, T.K., Lindecrona, R.H., Boye, M. and Moller, K. (2001) Culture-independent analysis of gut bacteria: The pig gastrointestinal tract microbiota revisited. Applied and Environmental Microbiology, 68, 673-690.

doi:10.1128/AEM.68.2.673-690.2002

[8] Pryde, S.E., Richardson, A.J., Stewart, C.S. and Flint, H.J. (1999) Molecular analysis of the microbial diversity present in the colonic wall, colonic lumen, and cecal lumen of a pig. Applied and Environmental Microbiology, 65, 5372-5377.

[9] Ruiz, R. and Rubio, L.A. (2009) Lyophilisation improves the extraction of PCR-quality community DNA from pig faecal samples. Journal of the Science of Food and Agriculture, 89, 723-727. doi:10.1002/jsfa. 3465

[10] Yu, Z. and Morrison, M. (2004) Improved extraction of PCR-quality community DNA from digesta and fecal samples. BioTechniques, 36, 808-812.

[11] Tang, J.N., Zeng, Z.G., Wang, H.N., Yang, T., Zhang, P.J., Li, Y.L., Zhang, A.Y., Fan, W.Q., Zhang, Y., Yang, X., Zhao, S.J., Tian, G.B. and Zou, L.K. (2008) An effective method for isolation of DNA from pig faeces and comparison of five different methods. Journal of Microbiological Methods, 75, 432-436. doi:10.1016/j.mimet.2008.07.014

[12] Ward, L.A. and Wang, Y. (2001) Rapid methods to isolate Cryptosporidium DNA from frozen feces for PCR. Diagnostic Microbiology and Infectious Disease, 41, 37-42. doi:10.1016/S0732-8893(01)00276-0

[13] Pontiroli, A., Travis, E.R., Sweeney, F.P., Porter, D., Gaze, W.H., Mason, S., Hibberd, V., Holden, J., Courtenay, O. and Wellington, E.M.H. (2011) Pathogen quantitation in complex matrices: A multi-operator comparison of DNA extraction methods with a novel assessment of PCR inhibition. PloS One, 6, 1-11.

doi:10.1371/journal.pone.0017916

[14] Stauffer, S.H., Birkenheuer, A.J., Levy, M.G., Marr, H. and Gookin, J.L. (2008) Evaluation of four DNA extrac- 
tion methods for the detection of Tritrichomonas foetus in feline stool specimens by polymerase chain reaction. Journal of Veterinary Diagnostic Investigation, 20, 639641. doi:10.1177/104063870802000518

[15] Yoon, K.P. and Hwang, C.L. (1995) Multiple attribute decision making: An introduction. SAGE Publications, London.

[16] Juteau, P., Tremblay, D., Villemur, R., Bisaillon, J.G. and Beaudet, R. (2004) Analysis of the bacterial community inhabiting an aerobic thermophilic sequencing batch reactor (AT-SBR) treating swine waste. Applied Microbiology and Biotechnology, 66, 115-122. doi:10.1007/s00253-004-1692-5

[17] Lemarchand, K., Berthiaume, F., Maynard, C., Harel, J., Payment, P., Bayardelle, P., Masson, L. and Brousseau, R. (2005) Optimization of microbial DNA extraction and purification from raw wastewater samples for downstream pathogen detection by microarrays. Journal of Microbiological Methods, 63, 115-126. doi:10.1016/j.mimet.2005.02.021

[18] Thermo Fisher Scientific (2009) Nanodrop 2000/2000c spectrophotometer, V1.0 user manual.

[19] Milani, A.S., Eskicioglu, C.K., Robles, K.B., Bujun, K. and Hosseini-Nasab, H. (2011) Multiple criteria decision making with life cycle assessment for material selection of composites. Express Polymer Letters, 5, 1062-1074.

[20] Jahan, A., Ismail, M.Y., Sapuan, S.M. and Mustapha, F. (2010) Material screening and choosing methods-A review. Materials and Design, 31, 696-705. doi:10.1016/j.matdes.2009.08.013

[21] Muyzer, G., Dewaal, E.C. and Uitterlinden, A.G. (1993) Profiling of complex microbial-populations by denaturing gradient gel electrophoresis analysis of polymerase chain reaction-amplified genes-coding for $16 \mathrm{~S}$ ribosomal-RNA. Applied and Environmental Microbiology, 59, 695-700.

[22] Rossmanith, P., Roder, B., Fruhwirth, K., Vogl, C. and Wagner, M. (2011) Mechanisms of degradation of DNA standards for calibration function during storage. Applied Microbiology and Biotechnology, 89, 407-417.

\section{doi:10.1007/s00253-010-2943-2}

[23] Life Technologies Corporation (2010) RNAlater ${ }^{\circledR}$ tissue collection: RNA stabilization solution. Product Information. Revision D. Part No. 7020M.

[24] Wang, S.S., Sherman, M.E., Rader, J.S., Carreon, J., Schiffman, M. and Baker, C.C. (2006) Cervical tissue collection methods for RNA preservation: Comparison of snap-frozen, ethanol-fixed, and RNAlater-fixation. Diagnostic Molecular Pathology, 15, 144-148. doi:10.1097/01.pdm.0000213460.53021.cd

[25] Cheung, A.L., Eberhardt, K.J. and Fischetti, V.A. (1994) A method to isolate RNA from gram-positive bacteria and mycobacteria. Analytical Biochemistry, 222, 511-514. doi:10.1006/abio.1994.1528

[26] Tell, L.A., Foley, J., Needham, M.L. and Walker, R.L. (2003) Comparison of four rapid DNA extraction techniques for conventional polymerase chain reaction testing of three Mycobacterium spp. that affect birds. Avian Diseases, 47, 1486-1490. doi:10.1637/7070

[27] Via, L.E. and Falkinham, J.O. (1995) Comparison of methods for isolation of Mycobacterium avium complex DNA for use in PCR and RAPD fingerprinting. Journal of Microbiological Methods, 21, 151-161. doi:10.1016/0167-7012(94)00045-9

[28] Scupham, A.J., Jones, J.A. and Wesley, I.V. (2007) Comparison of DNA extraction methods for analysis of turkey cecal microbiota. Journal of Applied Microbiology, 102, 401-409. doi:10.1111/j.1365-2672.2006.03094.x

[29] Barnard, T.G., Robertson, C.A., Jagals, P. and Potgieter, N. (2011) A rapid and low-cost DNA extraction method for isolating Escherichia coli DNA from animal stools. African Journal of Biotechnology, 10, 1485-1490.

[30] Hwang, C.L. and Yoon, K. (1981) Multiple attributes decision making-methods and applications. Springer, Berlin Heidelberg, New York.

[31] Shih, H.S., Shyur, H.J. and Lee, E.S. (2007) An extension of TOPSIS for group decision making. Mathematical and Computer Modelling, 45, 801-813. doi:10.1016/j.mcm.2006.03.023 